\title{
The Relevance of Notions of Risk and Uncertainty in Investment Decision to Base at Local
}

\author{
Veronica Pasa Stignei, University Spiru Haret Constanta, Romania
}

\begin{abstract}
Investing resources in the local public interest objectives locally involves taking risks caused by system operation and efficiency level established. Uncertainty and risk meet anywhere (even local government), combined in different proportions, so that the process has consciously assumed taking place in every field of activity, uncertainty can be eliminated.
\end{abstract}

\section{Keywords}

public investment decision, investment risk, uncertainty

JEL Code: $H 79$

Public administration is an operating system ${ }^{1}$ after its own principles, but is influenced by certain developments in society that is integrated. The quality that defines this particular system is that decisions are produced according to the particular set of public authorities and not by impersonal market forces. However, these priorities can be supported by the monopoly of state action, on the legitimate use of force and coercion.

Although always rely insufficient allocation of financial resources, there was a wrongful their management, characterized by waste of funds and public consumption unnecessarily. In addition, European officials always raises the need to improve Romania's administrative capacity to absorb EU funds, and enhanced budgetary constraints. I think the ultimate solution for achieving these requirements is to import the public sector management methods and techniques of specific resources of the private sector, without losing sight of specific public administration.

In European countries, public sector includes organizations that occupy a wide range of activities, the supply of electricity or telecommunications to health services. The specific public policy-making depends on the specific nature of their work, but they are competing with private sector companies. Therefore instruments specific strategic and tactical decisions, applies equally both public organizations and private ones, but the difference is that the purpose of public institutions not for profit. The European Commission recently adopted the concept that state subsidies are not compatible with the Treaty of Rome, public organizations are under increasing pressure, to implement competitive economy rules.

Issues of administrative decentralization and local self-governments have become major concerns of society, especially in solving the problems of ethnic minorities, cultural or linguistic. Decentralization is a fundamental process of moving power from center to periphery and generates a multitude of effects such as: grouping peripheral relations in the local environment (by changing the view about the rationality of government), location and intersection of these relations lead to an administrative system the specific it supports local power, local officials are no longer mere performers of directives from the central government, but they acquire the strategic capacity of action, decentralization policy creates

${ }^{1}$ Mihaela Onofrei (2007) "Elements of science administration" Publisher "Alexandru Ioan Cuza", p. 21 
the transfer of jurisdiction, determined to strengthen solidarity and development of local business, creating a new framework in around which the various local actors will have incentives to mobilize.

Decision is essential act of leadership to solve a given problem, which is accomplished by conscious choice of several versions of possible actions, to that which allows the rational use of human, material, financial and information in order to achieve the intended purpose, with highest economic and social efficiency. administrative decentralization process profoundly changes the reference and the conditions are selected targets based options and decisions . Local agent acts as a component of a political environment and administrative decisions are product specific variables of local origin, which central government can not collect them.

The administrative decentralization and local self-development to reach a wider political participation and involvement from the public (they are more involved in management of their localities), but not achieve a significant improvement in efficiency of resource allocation. The decentralization scheme, no decision is taken on behalf of and for the State, by one of its officials, but on behalf of local human and corporate, by a body emanating from it.

Local autonomy is a modern form of expression of the principle of administrative decentralization and means the right to self-administration. It is associated with the establishment of a separate status of local authorities in relation to state government as a way of smooth integration of all local interests to general interests of a material, or territorial basis of our state. The local government has the right within their powers, to cooperate and associate with other similar authorities in the country or abroad, to arrangements between themselves and participate in the development of regional development programs. It is important to note that a genuine local autonomy can exist only in so far as financial autonomy is ensured, a transfer of competences from central to local level, which amounts to a self-government, without the existence of skills in mobilizing resources from local budgets, leading ultimately negatively affect the level of satisfaction of local interests.

Customizing, administrative decision is the choice of a rational process of decision options, the more possible to achieve the government target. Administrative decision can be defined as a manifestation of the will of an organ of government in which he opts for a solution to allow implementation of an object. For administrative decision to ensure the maximum efficiency with the intended purpose, it to meet requirements, the most important being ${ }^{2}$ :

1. To be scientifically, legal and social. (Scientific validity of the decision shall remove practice, routine, chance, improvisation, subjectivism);

2. To be the result of the management team and to stimulate citizens' initiative. Modern management determines teamwork, in which the leader (mayor) acting as catalyst. In the administration, the team must draw and informing the citizens and decision-making.

3. To be pragmatic and simple. (Any administrative decision should have a practical use, so it needed a comprehensive and complete assessment of the economic and social administrative and territorial unit, taking into account the specific problems of local and national).

4. To be appropriate. (administrative decision must be taken of the body right time, knowing the local administration bodies best local social needs. It should be noted that in taking decisions, local bodies take account of normative acts developed by the central government which, in turn, is consult directly with local representatives).

5. To have systemic character. (Administrative decision will be integrated into administrative decisions taken previously, thus disappearing overlaps and contradictions between different decisions. Nature of the system ensures consistency of administrative decision, administrative decision being determined by the particular content and participants in decision making. administrative decision is output business officials, specialists, citizens, and collaboration between departments administrative structure).

\footnotetext{
${ }^{2}$ Vasile Munteanu (2008) "Comparative Public Management", Ed SEDCOM LIBRIS Iasi, p. 330
} 
Consultation of citizens in local issues of particular interest is stated by law. Citizen participation in decisions and help increase their opportunity to meet a higher standard of local requirements and ensure adherence of citizens in administrative decisions and simplify the process of implementing them. Specifically, citizens and NGOs can participate in such managerial decisions: the presence in the collective governing bodies of state administration; suggestions / proposals for new decisions and improve the pending. In our country, the principle of consultation with citizens is only said, but not implemented in administrative management.

Economic development is "the process by which local and / or community based groups, used existing resources and enter into a commitment to partnership with the private sector to create jobs and stimulate economic activities in an area economic well-defined ". The process of economic development, local communities can better manage their own resources and can increase the welfare of its inhabitants. A strength of decentralized economic development, is that people are more related to community life. Thus, locally can better quantify community needs, and under a sense of local identity, citizens are directly interested in the town where they live to grow more and more, because they will live better. Citizen involvement in strategic planning and economic development of their permanent information about project progress and results achieved, a prerequisite to provide support to citizens in community activities, in addition, citizens feel they are directly interested in community development.

Investment decision of the local government involves expectations from those that trigger the investment, but these expectations could be affected by events whose sources are multiple, but SIU contingencies. Financial analysis allows a rapid assessment of risk. Authority work is conducted under the influence of a certain degree of uncertainty generated by economic and financial environment, requiring a greater adaptability and flexibility.

Risk on investment decisions of local government is characterized by not known with certainty the characteristics of future events affecting the project investment, but known number of possible alternatives of those values and the likelihood of each. Investing resources involves taking risks caused by system operation and efficiency level established. This raises the risks of economic, political, cultural, social, technical, etc., forming the total investment risk. The projects have a specific life cycle, and therefore the risks should be pursued over the period. Uncertainty for investment projects change with his passing from one phase to another life cycle, means overcoming a state of complete uncertainty. The risk is an expected loss associated with the occurrence of future adverse situations. What you need to know local government is the nature of risk, its potential size and the main factors fueling it.

In the process of investment analysis and risk assessment, it is necessary to take into account inaccuracies in the figures used in the trial and error in considering whether investment, type of investment made and funding used and duration of the investment objective. Investment risk may take the following forms: inflation risk (the risk that the national currency to lose value of money), risk maturity (the non-risk debt outstanding over seven days), political risk (the change of government and denial of continued investment) Operational Risk (potential losses resulting from a bad management, lack of contracts / delays in their work, fraud). Business risk (economic risk) describes the "change to the projections (forecasts) of future income on assets or shares, if not used debt to finance its activities and can be changed over time. Appears as a result of inadequate or loss. Economic risk shows the administration's capacity to adapt in time with the lowest cost (public money always insufficient) efforts and economic environment in which operates. Economic risk depends on the composition of expenditure in the budget, the behavior to the workload, the low activity of investment management and effective administration. The structure of expenditure is reflected best in Cost - Profit - Volume and the neutral point or "dead". Economic risk will be even lower as this stalemate will be lower. Replacement investments have a very low risk, because they involve changes in technology. Modernization investments are characterized by a low-risk, 
due to minor corrections in manufacturing technology. Expansion and strategic investments entail a considerable risk, led to the need of increasing market supply, labor, capital and outlets.

Financial risk arises ${ }^{3}$ whether the local government funding needs of internal and external loans, so the debt. Financial risk expresses the inability of local government authority to honor the obligations arising from loans due date (and interest rates costs). If you are in the position of financial risk of becoming so, will have to take decisions amending financing strategy for local investment. Borrowing capacity is a key element in attracting financing resources of self-financing. Considered insufficient requiring in light of the existence of a coherent strategy to improve local government access to credit market is to set policy guidelines and measures leveraged technical and financial support, made under the risk profile. In Romania most local entities and local companies are in level two risk, that have the ability to access market financing, but is indebtedness due to high and low margins, which is incompatible with the financing of infrastructure investments. This group of local authorities could benefit from a support package that includes both technical assistance and also financial support. In understanding the World Bank technical assistance package would aim to reinforce the fiscal and financial management and quality management of local entities in the group, the aim being to enable them to reach market access through their own credit. As these entities reinforce their management capacity, the World Bank proposes to develop a part of Credit Guarantee Facilities (FGPC) with a model similar facilities that have been implemented successfully in the secondary mortgage market development in several developing economies. For municipalities with increased risk may be allocated from state budget grants conditional capital to finance local investment with a very high priority from an economic perspective, social or environmental, including European funds necessary financing.

The risk of short-term financial transactions can be highlighted in the following categories of risks: lack of liquidity risk, the risk of freezing (the administration is unable to repay loans due to the need to draw up risk funds), and the lack of profitability. The risk of long-term financial operations ensure that the operation of investment projects undertaken do not result in degradation of self-financing, and risk must consider conjuncture that could occur (for this administration should be able to attract resources surplus).

Local government debt must be properly structured in terms of interest rates, maturity and the currency loans. A weak structure of these elements may be contributing factor to the outbreak or spread of economic crisis. Recent economic crisis has highlighted the need to limit exposure to liquidity risk and other risks that are as local economies become vulnerable to external shocks. A sound risk management in local public sector is therefore paramount for risk management in other sectors of the economy, as economic entities in the private sector are facing serious problems when poor risk management, which he faces state and local government, opens the possibility of a liquidity crisis.

Market risk is measured, then, according to increasing debt service generated by changes in interest rate and exchange rate, compared to its predictability. It should also be taken into account real economic losses that may result from the increase or that the state can not refinance debt. Management involves managing multiple types of risks. One of the important tasks of the managing local public debt is to identify these risks, their evaluation as far as possible, and develop a strategy for arbitration costs and foreseeable risks. Policies debt portfolio management and risk shall be implemented after approval by the Government . The experience of other countries shows that the main objective of public debt management is to reduce debt costs and successful management of risks it generates. Local government in Romania calls on foreign debt is currently at the expense of internal, which increases the financial risk related to capital borrowed. IMF recommends developing a debt management structures to identify and manage what can be achieved arbitration between expected costs

\footnotetext{
3 Mihaela Onofrei (2008) "Financial Management", Ed CHBECK, Bucharest, p. 104
} 
and risks inherent in the debt portfolio. The cost of debt is composed of two elements: financial cost (debt service on medium and long) and the potential cost of real economic losses that may result from a financial crisis if the difficulties in refinancing debt or is unable to repay. IMF believes that pursuing credible in fiscal, monetary and financial sector will improve the current economic situation, however, risks remain high.

Resolute implementation of government policies is essential to restoring public confidence and economic growth, continuing cooperation with local authorities. The risks of implementation and application of investment programs will be significant, requiring harsh policies, sustainable related public expenditure.

Risks specific financing local public investments relate to:

- State budget allocations to the reduced amount or at all;

- Financing costs too high, unjustifiable and unacceptable or difficult to access in terms of political support;

- conditioning of favorable credit conditions only ensure the Romanian Government;

- that insufficient credit guarantees achievable only with support from national level;

- EU funding available late or unable to access government support results in late to the urgency to achieve the objective;

- Liquidity problems of local government budgets, foreign exchange risks;

- risk of interest changed at short intervals of time (which affects credit costs);

Risks specific investment projects can be overcome in light of experience gained by the teams responsible for the project. Implementation of methods and techniques for analyzing risk in the investment management system involving different types of resources that local government should have and use them for this purpose. The local authority must have primarily financial, material, human and informational, they will analyze the cost-benefit terms, in order to streamline the work of making the correct decision.

To reduce risks to adopt models for financing the direct involvement of the Romanian Government, central government authorities, local as well as the European financial institutions, limited credit risks under the contract, to create reserves of risk / liquidity of own funds local authorities.

Uncertainty and risk meet anywhere (even local government), combined in different proportions, so that the process has consciously assumed taking place in every field of activity, uncertainty can be eliminated. The uncertainty arises in decision making both by external factors determine the environment, but also by human factors governor. Uncertainty is the complement of knowledge, whereas the difference between what is known and what is known to be taken the right decisions, or the disparity between information and environment.

\section{References:}

1. Bebesel Mihaela (2008) - "Financial management of public institutions", Ed Wallachia, Constanta;

2. Mihaela Onofrei (2007) "Elements of science administration" Publisher "Alexandru Ioan Cuza";

3. Mihaela Onofrei (2008) "Financial Management", Ed CHBECK, Bucharest;

4. Stoina Cristian Nicolae (2008) "Risk and uncertainty in investment", Ed Teora, Bucharest;

5. Vasile Munteanu (2008) "Comparative Public Management", Ed SEDCOM LIBRIS, Iasi; 